Review

\title{
Brassinosteroids (BRs) Role in Plant Development and Coping with Different Stresses
}

\author{
Hakim Manghwar ${ }^{1, *(\mathbb{D}}$, Amjad Hussain $^{2}\left(\mathbb{D}\right.$, Qurban Ali $^{3}$ and Fen Liu $^{1, *}$ \\ 1 Lushan Botanical Garden, Chinese Academy of Sciences, Jiujiang 332000, China \\ 2 National Key Laboratory of Crop Genetic Improvement, Huazhong Agricultural University, \\ Wuhan 430070, China; ad_hn@outlook.com \\ 3 Key Laboratory of Monitoring and Management of Crop Diseases and Pest Insects, Ministry of Education, \\ Nanjing Agricultural University, Nanjing 210095, China; qurbanalirattar@webmail.hzau.edu.cn \\ * Correspondence: hakim@lsbg.cn (H.M.); liuf@lsbg.cn (F.L.)
}

Citation: Manghwar, H.; Hussain, A.; Ali, Q.; Liu, F. Brassinosteroids (BRs) Role in Plant Development and Coping with Different Stresses. Int. J. Mol. Sci. 2022, 23, 1012. https:// doi.org/10.3390/ijms23031012

Academic Editor: Jana Oklestkova

Received: 23 December 2021

Accepted: 14 January 2022

Published: 18 January 2022

Publisher's Note: MDPI stays neutral with regard to jurisdictional claims in published maps and institutional affiliations.

Copyright: (C) 2022 by the authors. Licensee MDPI, Basel, Switzerland. This article is an open access article distributed under the terms and conditions of the Creative Commons Attribution (CC BY) license (https:// creativecommons.org/licenses/by/ $4.0 /)$.

\begin{abstract}
Plants are vulnerable to a number of abiotic and biotic stresses that cause a substantial decrease in the production of plants. Plants respond to different environmental stresses by experiencing a series of molecular and physiological changes coordinated by various phytohormones. The use of phytohormones to alleviate stresses has recently achieved increasing interest. Brassinosteroids (BRs) are a group of polyhydroxylated steroidal phytohormones that are required for the development, growth, and productivity of plants. These hormones are involved in regulating the division, elongation, and differentiation of numerous cell types throughout the entire plant life cycle. BR studies have drawn the interest of plant scientists over the last few decades due to their flexible ability to mitigate different environmental stresses. BRs have been shown in numerous studies to have a positive impact on plant responses to various biotic and abiotic stresses. BR receptors detect the BR at the cell surface, triggering a series of phosphorylation events that activate the central transcription factor (TF) Brassinazole-resistant 1 (BZR1), which regulates the transcription of BR-responsive genes in the nucleus. This review discusses the discovery, occurrence, and chemical structure of BRs in plants. Furthermore, their role in the growth and development of plants, and against various stresses, is discussed. Finally, BR signaling in plants is discussed.
\end{abstract}

Keywords: brassinosteroids (BRs); plant; biotic stress; abiotic stress

\section{Introduction}

Plants are exposed to a wide range of biotic and abiotic stresses throughout their life cycle and need to constantly regulate their physiological and developmental processes for responding to numerous internal and external stimuli [1]. Various biotic and abiotic stresses significantly contribute to major global crop production losses by primarily influencing the stress tolerance/adaptive ability of plants [2]. Plants utilize various signaling molecules, including hormones for mediating the plant response to the number of stresses [3,4]. Phytohormones have been widely considered as the natural activators for plant growth and development. They maintain healthy life in plants, and play an essential role in defense mechanisms against various stresses [5]. Phytohormones initiate a signaling cascade that involves a number of molecular players, which lead to an ideal generic pathway [6]. Brassinosteroids (BRs) are an important group of plant hormones involved in regulating plant growth and development, and they help plants to adapt to the environment [7]. Biosynthesis and signaling of the hormone have been extensively studied since its discovery, particularly in the Arabidopsis (Arabidopsis thaliana), which led to a comprehensive understanding of BR synthesis and its signaling pathways [8,9]. Here, we discuss the discovery, occurrence, and the chemical structure of BRs in plants. Moreover, the role of BRs in plant growth and development, and against various kinds of stresses, is discussed. Finally, their signaling in plants is discussed. 


\section{Discovery of BRs in Different Plant Species}

BRs were initially discovered in Brassica napus pollen on the basis of their ability to promote growth [10]. BRs have been discovered as stimulants for plant cell elongation and division. BRs were subsequently named 'brassins'. Brassinolide (BL), the most active BR, was isolated in 1979 [11]. The most significant finding was the isolation of Brassinosteroid insensitive 1 (BRI1) - a receptor kinase that triggers an intracellular signaling cascade in response to extracellular BR perception [12]. Since the discovery of BL, a huge number of chemically different BRs have been discovered throughout the plant kingdom, including green algae and land plants, suggesting that BRs evolved early during plant evolution. BRs were identified as plant hormones after discovering BR-deficient mutants in A. thaliana [13]. Among all BRs studied to date, Castasterone (CS), Typhasterol (TY), Brassinolide (BL), 6-deoxocastasterone (6-deoxoCS), 28-norcastasterone (28-norCS), and Teasterone (TE) are commonly present in various plant species throughout different environments [14-16].

\section{Occurrence of BRs in Plants}

BRs have been found in organs and all parts of the plants, such as leaves, stems, roots, flowers, pollen, anthers, and seeds [17,18]. BR is universally distributed in all growing tissues of higher plants, but significantly higher concentrations have been detected in seed, pollen, and fruit [19]. The level of BR in the young tissues (1-100 ng/g fresh weight) is normally higher than in mature ones $(0.01-0.1 \mathrm{ng} / \mathrm{g}$ fresh weight) [20]. BL and CS are the most significant BRs because of their higher biological activity and widespread distribution in plants. However, due to its commercial availability, 24-epibrassinolide (EBR) is the most commonly used BR for studying the physiological effects of exogenous steroid phytohormones on plants [21].

After the BL discovery, about 69 BRs have been identified in 64 plant species, including 6 gymnosperms, 53 angiosperms (41 dicotyledons and 12 monocotyledons), 1 pteridophyte (Equisetum arvense), 3 algae (Hydrodictyon reticulatum, Cystoseira myrica, and Chlorella Vulgaris) and 1 bryophyte (Marchantia polymorpha) [17,18], a moss (Physcomitrella patens), lycophytes (Selaginella moellendorffii and S. uncinata), and 13 fern species [22]. The concentration of 6-deoxotyphasterol (6-deoxoTY) concentration was found to be 6400-fold greater than BL in the pollen of Cupressus arizonica. Additionally, the highest concentration of $\mathrm{BR}, 6.4 \mathrm{mg}$ 6-deoxoTY per kilogram $(\mathrm{kg})$ pollen, has been found in C. arizonica [17]. Only 52 BRs have been reported in terms of their biological activities in plants [16]. The CS, BL, TY, 6-deoxoCS, TE, and 28-norCS are the most abundant BRs in plants $[14,15,20]$. The most extensive variety of BRs (2 conjugated and 25 free forms) was found in unripe bean (Phaseolus vulgaris) seeds [20]. Other legumes having fewer BR members have been found in shoots, seeds, and pollen, and their quantity was between 0.007 and $6281 \mathrm{~g} / \mathrm{g}$ fresh weight [14].

\section{Chemical Structure of BRs}

BRs have been categorized into three major types on the basis of each steroid molecule's carbon number (i.e., $\mathrm{C}_{27}, \mathrm{C}_{28}$, and $\mathrm{C}_{29}$ ) [23]. The $5 \alpha$-cholestane skeleton is the basic structure of $\mathrm{C}_{27}$-BRs, $5 \alpha$-ergostane for $\mathrm{C}_{28}$-BRs, while $5 \alpha$-stigmastane is the basic structure of $\mathrm{C}_{29}$-BRs. The structure of these hormones differs because of the type and orientation of oxygenated functions of $\mathrm{A}$ and $\mathrm{B}$ rings, and the number and position of functional groups in the side chain of the molecule. These changes occur as the result of oxidation and reduction reactions during biosynthesis. In general, BRs have been classified into conjugated (5) free, and (64) compounds [23].

BRs have vicinal hydroxyl groups in relation to the A-ring at C-2 $\alpha$ and C-3 $\alpha$. BRs with $\alpha$ and $\beta$-hydroxyls, or ketone at the C-3 position are the progenitors of the BRs with $2 \alpha$, $3 \alpha$-vicinal hydroxyls. BR containing $2 \alpha, 3 \beta-, 2 \beta, 3 \alpha-$, or $2 \beta, 3 \beta$-vicinal hydroxyls maybe the precursors of $2 \alpha, 3 \alpha$-vicinal hydroxyls. Two $2 \alpha, 3 \alpha$-vicinal hydroxyl groups on the A-ring are responsible for overall structural attributes of the most active BRs, such as BL and CS. The declining order of activity $2 \alpha, 3 \alpha>2 \alpha, 3 \beta>2 \beta, 3 \alpha>2 \beta, 3 \beta$ suggests 
that the $\alpha$-oriented hydroxyl group at C-2 is essential for biological activity of BRs in plants $[24,25]$. On the basis of cholestane side chain, BRs have been divided by different substituents into C-23, C-24, and C-25: 23-oxo (4 compounds), 24-methylene (3 compounds), 24S-ethyl (4 compounds), 24R-methyl (5 compounds), 24S-methyl (23 compounds), C-25, 24ethylidene (3 compounds), 24-methyl-25-methyl (3 compounds), 24-methylene-25-methyl (6 compounds) without substituent at C-23 (3 compounds), without substituent at C-24 (8 compounds), and without substituents at C-23, C-24 (2 compounds) [26-28].

BRs are classified into 6-oxo (6-ketone) (34 compounds), and 6-deoxo (non-oxidized) (21 compounds), and 7-oxalactone (12 compounds) types depending on B-ring oxidation stage. However, only one fourth type BR with hydroxyl group at C-6, such as $6 \alpha$-hydroxycastasterone (6 $\alpha$-OH-CS) has been observed. In contrast, two compounds, for instance, 28-nor-(22S)-22hydroxycampestrol (28-nor-22-OHCR) and (22S)-22-hydroxycampestrol (22-OHCR) were identified as a fifth type of BRs. Generally, 7-oxalactone BRs have been observed to show stronger biological activity compared to 6-deoxo type, and 6-oxo type. Sometimes 6-oxo BRs show activity similar to 7-oxalactone compounds, while non-oxidized BRs exhibit essentially little activity in the bean internode test or very little in the rice lamina inclination test [29-31].

\section{Role of BRs in Growth and Development of Plants}

BRs are steroid hormones that play various roles in the growth and development of plants [32-34] (Figure 1). BRs regulate various developmental and physiological processes in plants, such as expansion, cell division, stem cell maintenance, vascular development, elongation of different cell types, and floral transition [35-38]. Moreover, they play diverse roles in hypocotyl elongation [39], root growth [7,40], shoot growth [28], stomata patterning [41,42], pollen tube growth, seed germination, and pollen germination and development [43], treachery element differentiation [44], xylem formation [45,46], xylem differentiation, photomorphogenesis and plant reproduction [47,48], and senescence [49]. BRs have the ability to activate the cell cycle during seed germination [50], regulate cell cycle progression [51], control leaf cells' proliferation [52], and induce excessive growth in hydroponically grown plants [53]. BRs also regulate the abiotic and biotic stress responses and stomata development $[7,34,54]$. Moreover, BR plays a vital role in regulating male and female fertility in crops $[55,56]$. BR plays a role in etiolation and promotes the elongation of stigma [19], plant architecture, thermo-tolerance, proton transport, tiller number, leaf angle, and leaf size $[57,58]$. In addition, the exogenous application of BR or alteration in their biosynthesis and signaling could improve crop yields [59,60].

BRs are also involved in the regulation of several genes in plants (Table 1). In a study, Chen et al. [61] found that BRs induced WRKY46, WRKY54, and WRKY70 genes that were observed to play positive roles in BR-regulated plant growth in A. thaliana. In another study, the histone lysine methyltransferase SDG8 is involved in BR-regulated gene expression. The knockout mutant $s d g 8$ displayed a reduced growth phenotype with compromised BR responses in A. thaliana [62]. In A. thaliana, BR regulates the seed development and affects the seed size/weight and number by transcriptionally modulating the genes and pathways that regulate the development of the seed and ovule $[63,64]$. Furthermore, BRs regulate root Nitrogen foraging response in $A$. thaliana during mild Nitrogen deficiency. A Brassinosteroid signaling kinase 3 (BSK3) gene is involved in the elongation of primary root during mild Nitrogen deficiency [65].

BR regulates the grain yield and plant architecture in rice [23]. The gene products of $B R D 1$ and $D 11$ are involved in the biosynthesis of $\mathrm{BR}$, and affect the height of rice plants [66]. The OsDwarf2/OsDwarf1 reduction encodes a C-6 oxidase needed for BR biosynthesis in rice, reducing second internode and seed length elongation $[66,67]$. In rice, $\mathrm{BRs}$ mediate the effects of $\mathrm{N}$ fertilization on spikelet development and contribute to promote spikelet growth by increasing the level of antioxidant system (AOS) and energy charge during panicle development [68]. In maize, inadequate BR biosynthesis causes male sterility due to failure of pollen and anther growth $[55,56]$. In cotton, both the fiber initiation and elongation of cultured cotton ovules have been reported to require BRs [69,70]. 
Moreover, an exogenous application of EBR delays the vegetative to generative transition in monocotyledonous wheat (Triticum aestivum L.). Brassinazole, a BR inhibitor, accelerates the transition and heading stage [71]. The application of BR accelerated winter rapeseed maturation by 4 to 8 days [72].

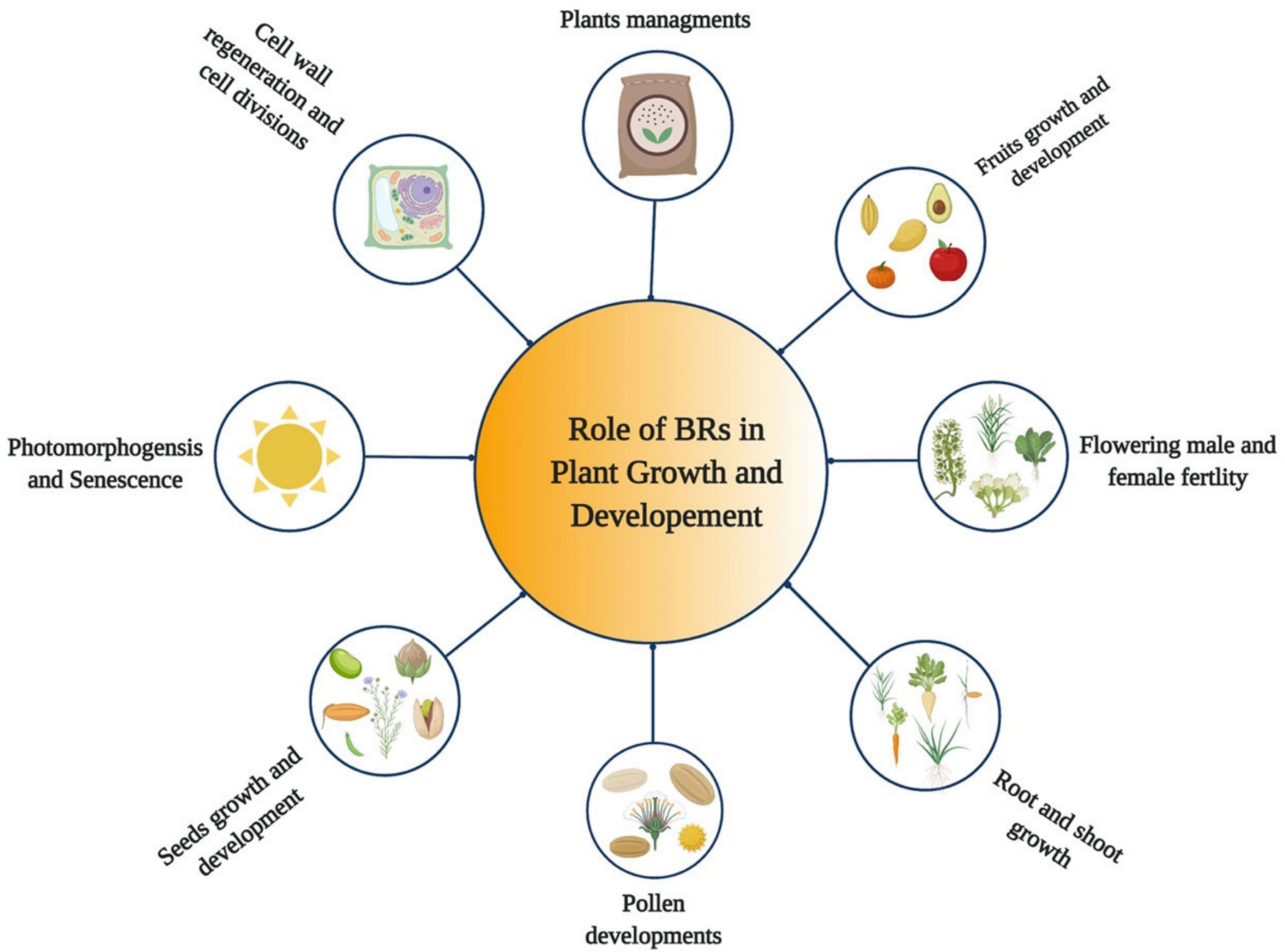

Figure 1. Role of Brassinosteroids (BRs) in growth and development of plants.

Priming of lucerne seeds with BL considerably increased length, vigor, and fresh and dry shoot and root weights [73]. The application of BR promoted the ripening of grape berry [74]. Treatment with EBR was observed to substantially increase sucrose synthase (sucrolytic) and soluble sugars content in berries [75]. Treatment with BR helped in reducing the decay of jujube fruits, likely due to its ability to postpone senescence and induce disease resistance [76]. Additionally, in potato tubers, the BRs have been shown to promote apical meristem growth [77], accelerating the cell division rate in isolated protoplasts of Petunia hybrida [78]. In Pharbitis nil, CS and BL treatments inhibit flowering in combination with the inductive photoperiod, implying that BR works in tandem with environmental cues to ensure the proper reproductive transition $[19,79]$.

BRs can participate in physiological processes in response to stress by tuning plant growth, and improving plant performance by interacting with plant growth regulators or other plant hormones [80,81]. The disruption of BR signaling affects several developmental processes, including seed development [64], pollen development [82], and flowering time [83]. Plants with BR deficiency are dwarfed [84], and exhibit altered stomatal development $[41,85]$, reduced male fertility, shortened hypocotyls, petioles and internodes, downward curled leaves, and delayed flowering [82]. Moreover, BR-deficient plants also have a compact plant structure because of the reduced lamina inclination. However, BR deficiency can reduce grain size, seed fertility and tiller number [9], improper stomatal distribution, and reduce seed germination [86]. BR-insensitive and -deficient mutants are often referred to as late flowering due to their retarded growth $[87,88]$. In contrast, 
plants over accumulating BRs display elongation of petioles and hypocotyls and increased height [89].

Table 1. Involvement of various Brassinosteroid-regulated genes in plant growth and development.

\begin{tabular}{|c|c|c|c|c|}
\hline Gene & Description of Gene & Crop/Plant & Role in Growth & Reference \\
\hline CESA & $\begin{array}{l}\text { The CESA gene } \\
\text { superfamily, encoding } \\
\text { the catalytic subunits of } \\
\text { cellulose synthase }\end{array}$ & $\begin{array}{l}\text { Arabidopsis } \\
\text { (A. thaliana) }\end{array}$ & $\begin{array}{l}\text { Plays a role in regulating the } \\
\text { cellulose synthesis }\end{array}$ & [90] \\
\hline CYCD3;1 & Cell division markers & $\begin{array}{l}\text { Arabidopsis } \\
(\text { A. thaliana })\end{array}$ & $\begin{array}{l}\text { Needed for normal cell } \\
\text { cycle progression }\end{array}$ & {$[51]$} \\
\hline $\begin{array}{c}\text { Histone lysine } \\
\text { methyltransferase SDG8 }\end{array}$ & $\begin{array}{l}\text { In Arabidopsis, there are } \\
43 \text { SET Domain Groups } \\
\text { (SDG), which contain } \\
\text { proteins with conserved } \\
\text { SET domains }\end{array}$ & $\begin{array}{l}\text { Arabidopsis } \\
\text { (A. thaliana) }\end{array}$ & $\begin{array}{l}\text { Involved in BR-regulated } \\
\text { gene expression }\end{array}$ & {$[62]$} \\
\hline $\begin{array}{l}\text { WRKY } 46, W R K Y 54 \\
\text { and WRKY70 }\end{array}$ & $\begin{array}{l}\text { The WRKY family TFs } \\
\text { are composed of over } 70 \\
\text { members in Arabidopsis }\end{array}$ & $\begin{array}{l}\text { Arabidopsis } \\
\text { (A. thaliana) }\end{array}$ & $\begin{array}{l}\text { Play positive roles in } \\
\text { BR-regulated plant growth } \\
\text { and drought stress }\end{array}$ & {$[61]$} \\
\hline $\begin{array}{c}\text { Brassinazole-resistant } 1 \\
\text { (BZR1), and } \\
\text { BES1-interacting } \\
\text { MYC-like proteins (BIMs) }\end{array}$ & $\begin{array}{l}\text { BZR1; BR-activated } \\
\text { transcription factor (TF) } \\
\text { and BIMs; bHLH TF }\end{array}$ & $\begin{array}{l}\text { Arabidopsis } \\
\text { (A. thaliana) }\end{array}$ & $\begin{array}{l}\text { BR signaling promotes } \\
\text { vegetative growth by } \\
\text { inhibiting the } \\
\text { floral transition }\end{array}$ & [91] \\
\hline $\begin{array}{l}\text { Transcripts of } \\
\text { autophagy-related } \\
\text { genes }(A T G s)\end{array}$ & Autophagy-related genes & $\begin{array}{c}\text { Tomato } \\
\text { (Solanum lycopersicum) }\end{array}$ & $\begin{array}{c}\text { Enhanced level of BR } \\
\text { triggers } A T G s \text { and formation } \\
\text { of autophagosomes }\end{array}$ & [92] \\
\hline$V v H M G R$ & $\begin{array}{l}\text { Plays a role in the } \\
\text { mevalonate } \\
\text { (MVA) pathway }\end{array}$ & $\begin{array}{l}\text { Grape berries } \\
\text { (Vitis vinifera) }\end{array}$ & $\begin{array}{l}\text { Involved in increasing } \\
\text { the anthocyanin content and } \\
\text { promoting coloration. } \\
\text { Accumulates the fruit sugar } \\
\text { components, and decreases } \\
\text { the tartaric acid content }\end{array}$ & [93] \\
\hline
\end{tabular}

\section{Role of BRs against Different Stresses in Plants}

BRs play various roles against different kinds of biotic and abiotic stresses [94,95] (Figure 2). Various studies have shown that BRs play an essential role in acclimation to environmental stresses, resistance to pathogens, and cell elongation, resulting in increased crop yield and plant growth [13]. Therefore, these compounds can be used as biostimulants in crops to induce abiotic stress tolerance and to improve plant efficiency [80]. These compounds play a vital role to alleviate various stresses, such as drought [96,97], cold [98,99], heat [100,101], and salinity [102,103] by increasing the photosynthesis and biomass, strengthening antioxidant enzymes and the potential of detoxification as well as stimulates the expression of related genes [104,105]. BRs are also involved in oxidative stress, heavy metal stress response, and pathogen attack $[104,106]$. BRs play a crucial role in protecting plants from antimony (Sb) toxicity [107]. BRs have been involved in regulating various metabolic pathways and also interact with many other plant growth regulators [59]. However, these regulatory functions indicate the important roles of BR in adapting to environmental changes [108].

Several studies have reported that BRs regulate many genes against different stresses in various crops (Table 2). Earlier studies indicated that BRs play positive roles in drought tolerance in Brassica napus, A. thaliana, and wheat (T. aestivum L.) [109]. For example, overexpression of $A$. thaliana BR biosynthetic AtDWARF4 gene in B. napus increased drought resistance [110]. In barley, the leaf disease at the tillering phase caused by Helminthosporium teres Sacc was reduced using 24 EBL [16]. The application of BRs has the potential in inducing tolerance against various plant diseases caused by the Tobacco mosaic virus 
(TMV) in tobacco and Xanthomonas oryzae and Maganoprothe grisea in rice [16,111]. The use of BRs has the potential to enhance defense against plant virus response by inducing several resistance genes and activating various vital antioxidant enzymes. Moreover, Cucumber mosaic virus (CMV) stress tolerance is stronger in bes1-D. However, BR signaling is required for BR-induced resistance to plant virus. In response to CMV infection, BR signaling can induce the expression of several resistance genes [112]. Furthermore, in response to chilling stress in tomato, the BRs regulate the NBR1-dependent selective autophagy in a BZR1dependent manner [113]. The exogenous application of EBR and 28-homobrassinolide (HBL) has been shown to mitigate the harmful effects of heavy metals on plants [114,115]. Moreover, Exogenous application of BR was observed to increase pepper tolerance against low-temperature stress [116].

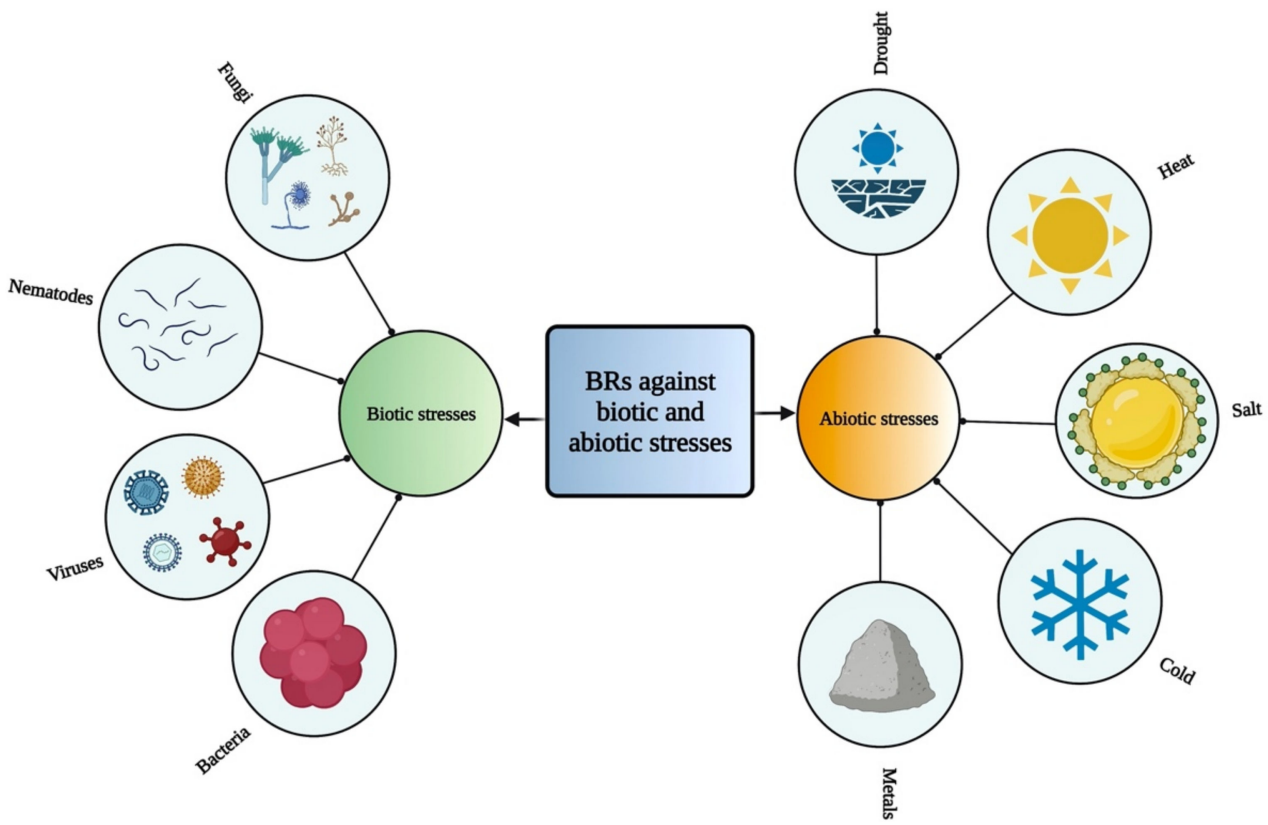

Figure 2. Role of BRs against different biotic and abiotic stresses in plants.

In a study, two important BR signaling components were shown to modulate the freezing tolerance in A. thaliana. The loss-of-function mutation in GSK3-like kinases (involved in BR signaling, bin2-3 bil1 bil2) mutants showed increased resistance to the freezing, while BIN2 overexpression exhibited hypersensitivity to freezing stress. By contrast, gain-offunction mutants of BZR1 and BES1 TFs showed increased resistance to the freezing [99]. The UBC32, a stress-induced functional ubiquitin conjugation enzyme (E2), which is localized in the ER membrane, connecting the ERAD process and BR-mediated growth promotion and tolerance to the salt stress. The mutant forms of BRI1, bri1-5, and bri1-9 were observed to be accumulated by the UBC32 mutation, and these mutant forms then activated the BR signal transduction [102]. A. thaliana WRKY46, WRKY54, and WRKY70 TFs were shown to play roles in plant growth and drought response regulated by the BR-as the wrky 46 wrky 54 wrky70 triple mutant exhibits defects in BR-regulated growth and more tolerance to the drought stress. WRKY54 interacts directly with BES1 for co-regulating the expression of target genes [61]. Moreover, Eremina et al. [98] showed that BRs regulate the freezing tolerance. BR signaling-defective mutants were found to show hypersensitivity to freezing before and after the cold acclimation in $A$. thaliana. In contrast, the constitutive activation of BR signaling showed more resistance to freezing.

Another study was conducted in order to check the response of BR on cadmium's effects on active oxygen metabolism and photosynthetic machinery in two tomato cultivars. The results showed a significant decrease in photosynthetic parameters, activity of several enzymes (carbonic anhydrase and nitrate reductase), and leaf water potential with the 
increasing levels of cadmium in the soil. BRs exogenous application increased the activity of photosynthetic machinery and antioxidant defense system, and nullified the detrimental effects of metal on these parameters [117]. A study in tomato shows the relationship between $\mathrm{BR}$ and $\mathrm{ABA}$ in inducing the production of $\mathrm{H}_{2} \mathrm{O}_{2}$ and their functions against paraquat $(\mathrm{PQ})$ oxidative and heat stresses. Both $\mathrm{BR}$ and $\mathrm{ABA}$ induced increases in $\mathrm{RBOH} 1$ gene expression levels, tolerance to the heat and PQ stresses, NADPH oxidase activity, and accumulation of apoplastic $\mathrm{H}_{2} \mathrm{O}_{2}$ in wildtype plants [118].

Table 2. Regulation of different stress-related genes by BRs.

\begin{tabular}{|c|c|c|c|c|}
\hline Gene/BRs & Gene Function & Crop/Plant & Stress Type & Reference \\
\hline $\begin{array}{l}\text { Respiratory burst oxidase } \\
\text { homolog }(\mathrm{RBOH})\end{array}$ & $\begin{array}{c}\text { Involved in } \\
\text { ROS generation }\end{array}$ & $\begin{array}{c}\text { Cucumber } \\
\text { (Cucumis sativus L.) }\end{array}$ & $\begin{array}{c}\text { Cold and } \\
\text { photo-oxidative stresses }\end{array}$ & [119] \\
\hline$D R E B$ & $\begin{array}{l}\text { Involved in regulating } \\
\text { various cold } \\
\text { stress-responsive genes }\end{array}$ & $\begin{array}{c}\text { Rice } \\
\text { (O. sativa L.) }\end{array}$ & Cold stress & {$[109,120]$} \\
\hline $\begin{array}{l}\text { Proline-5-caryboxylate } \\
\text { synthetase } 1 \text { (P5CS1) }\end{array}$ & $\begin{array}{l}\text { Involved in the } \\
\text { proline biosynthesis }\end{array}$ & $\begin{array}{l}\text { Arabidopsis } \\
\text { (A. thaliana) }\end{array}$ & Salt stress & [121] \\
\hline $\begin{array}{l}\text { Abscisic acid stress } \\
\text { ripening }(A S R)\end{array}$ & $\begin{array}{l}\text { Involved in signal } \\
\text { transduction }\end{array}$ & $\begin{array}{c}\text { Mango } \\
\text { (Mangifera indica L.) }\end{array}$ & Cold stress & [122] \\
\hline YODA $(Y D A)$ & $\begin{array}{l}\text { A TF involved in } \\
\text { regulating stomatal } \\
\text { conductance }\end{array}$ & $\begin{array}{l}\text { Arabidopsis } \\
\text { (A. thaliana) }\end{array}$ & Drought and salt stresses & {$[41]$} \\
\hline $\begin{array}{l}\text { CYP90b3, GSH1, } \\
\text { and GST1 }\end{array}$ & Play a role in detoxification & $\begin{array}{c}\text { Tomato } \\
\text { (S. lycopersicum L.) }\end{array}$ & Phenanthrene stress & [123] \\
\hline Remorin & Membrane skeleton protein & $\begin{array}{c}\text { Mango } \\
\text { (M. indica L.) }\end{array}$ & Drought stress & [122] \\
\hline UВС32 & $\begin{array}{l}\text { A stress-induced functional } \\
\text { ubiquitin conjugation } \\
\text { enzyme (E2) }\end{array}$ & $\begin{array}{l}\text { Arabidopsis } \\
\text { (A. thaliana) }\end{array}$ & Salt stress & [102] \\
\hline Lipocalins & $\begin{array}{c}\text { Involved in } \\
\text { signal transduction }\end{array}$ & $\begin{array}{c}\text { Mango } \\
\text { (M. indica L.) }\end{array}$ & Cold stress & [122] \\
\hline $\begin{array}{l}\text { Submergence 1A } \\
(\text { SUB1A) }\end{array}$ & $\begin{array}{l}\text { An ethylene response } \\
\text { factor (ERF), involved } \\
\text { in conferring } \\
\text { the submergence } \\
\text { tolerance }\end{array}$ & $\begin{array}{c}\text { Rice } \\
\text { (O. sativa L.) }\end{array}$ & Submergence tolerance & [124] \\
\hline $\begin{array}{l}\text { Alternative oxidase } \\
\text { (AOX) }\end{array}$ & $\begin{array}{l}\text { Involved in protecting the } \\
\text { plant photosystems }\end{array}$ & $\begin{array}{c}\text { Tobacco } \\
\text { (Nicotiana benthamiana) }\end{array}$ & Cold stress & [125] \\
\hline Ferritin & Involved in iron storage & $\begin{array}{c}\text { Rice } \\
\text { (O. sativa L.) }\end{array}$ & Pesticide and salt stresses & [126] \\
\hline $\begin{array}{c}\text { Respiratory } \\
\text { burst oxidase homolog } 1 \\
(R B O H 1)\end{array}$ & $\begin{array}{c}\text { Involved in } \\
\text { ROS generation }\end{array}$ & $\begin{array}{c}\text { Tomato } \\
(\text { S. lycopersicum })\end{array}$ & Heat tolerance & [118] \\
\hline $\begin{array}{c}\text { Ascorbate peroxidase } \\
(A P X)\end{array}$ & $\begin{array}{c}\text { Involved in the scavenging } \\
\text { of ROS }\end{array}$ & $\begin{array}{c}\text { Rice } \\
\text { (O. sativa L.) }\end{array}$ & Pesticide and salt stresses & {$[127,128]$} \\
\hline bes1-D & BRI1 EMS SUPRESSOR 1 & $\begin{array}{l}\text { Arabidopsis } \\
\text { (A. thaliana) }\end{array}$ & $\begin{array}{l}\text { Tolerance to Cucumber } \\
\text { mosaic virus (CMV) }\end{array}$ & [112] \\
\hline
\end{tabular}


Table 2. Cont.

\begin{tabular}{|c|c|c|c|c|}
\hline Gene/BRs & Gene Function & Crop/Plant & Stress Type & Reference \\
\hline $\begin{array}{l}\text { Superoxide dismutase } \\
(S O D)\end{array}$ & $\mathrm{H}_{2} \mathrm{O}_{2}$ biosynthesis & $\begin{array}{c}\text { Rice } \\
\text { (O. sativa L.) }\end{array}$ & Pesticide and salt stresses & {$[127,128]$} \\
\hline $\begin{array}{l}\text { Glutathione reductase } \\
\qquad(G R)\end{array}$ & $\begin{array}{l}\text { Involved in the scavenging } \\
\text { of ROS }\end{array}$ & $\begin{array}{c}\text { Rice } \\
\text { (O. sativa L.) }\end{array}$ & Pesticide and salt stresses & {$[127,128]$} \\
\hline Catalase $(C A T)$ & $\begin{array}{l}\text { Engaged in the scavenging } \\
\text { of ROS }\end{array}$ & $\begin{array}{c}\text { Rice } \\
\text { (O. sativa L.) }\end{array}$ & Pesticide and salt stresses & {$[127,128]$} \\
\hline $\begin{array}{c}\text { No-expressor of } \\
\text { pathogenesis-related } \\
\text { genes1-1 (NPR1-1) }\end{array}$ & $\begin{array}{l}\text { Involved in regulating } \\
\text { various stress- } \\
\text { responsive genes }\end{array}$ & $\begin{array}{l}\text { Arabidopsis } \\
\text { (A. thaliana) }\end{array}$ & $\begin{array}{l}\text { Salt and hyper- } \\
\text { thermal stresses }\end{array}$ & [129] \\
\hline $\begin{array}{c}\text { 1-aminocyclopropane-1- } \\
\text { carboxylate synthase } \\
(A C S)\end{array}$ & $\begin{array}{c}\text { An ethylene } \\
\text { synthesis enzyme }\end{array}$ & $\begin{array}{c}\text { Tomato } \\
(\text { S. lycopersicum })\end{array}$ & Salt stress & [103] \\
\hline Cesta $(C E S)$ & $\begin{array}{l}\text { TFs that are involved in } \\
\text { regulating several cold } \\
\text { stress-responsive genes }\end{array}$ & $\begin{array}{l}\text { Arabidopsis } \\
\text { (A. thaliana) }\end{array}$ & Cold stress & {$[98]$} \\
\hline$B Z R 1$ and $B E S 1$ & $\begin{array}{c}\text { Basic helix-loop-helix TFs } \\
\text { play a role in the } \\
\text { BR-signaling pathway }\end{array}$ & $\begin{array}{l}\text { Arabidopsis } \\
\text { (A. thaliana) }\end{array}$ & Freezing tolerance & [99] \\
\hline WRKY & $\begin{array}{c}\text { Involved in regulating } \\
\text { various stress- } \\
\text { responsive genes }\end{array}$ & $\begin{array}{l}\text { Arabidopsis } \\
\text { (A. thaliana) }\end{array}$ & Drought stress & {$[61]$} \\
\hline$B R L 3$ & $\begin{array}{l}\text { A vascular-enriched } \\
\text { member of the BR } \\
\text { receptor family }\end{array}$ & $\begin{array}{l}\text { Arabidopsis } \\
\text { (A. thaliana) }\end{array}$ & Drought stress & [96] \\
\hline BZR1 & $\begin{array}{c}\text { The main regulator of } \\
\text { BR response }\end{array}$ & $\begin{array}{c}\text { Tomato } \\
\text { (S. lycopersicum) } \\
\text { and Arabidopsis } \\
\text { (A. thaliana) }\end{array}$ & Thermotolerance & {$[100,101]$} \\
\hline
\end{tabular}

\section{BRs Signaling in Plants}

In the last two decades, the BR signal transduction pathway has been extensively studied and reported as a complex pathway. The transduction pathway has a critical role in the growth and development of plants. The signal transduction pathway demonstrates that plant-specific leucine-rich repeat (LRR) receptor kinase located on the plasma membrane perceives BRs outside the cell. BRI1 interacts with BRI1-associated receptor kinase 1 (BAK1) and regulates the important positive regulators of the BR signaling, BZR1 and BES1 [130]. Increased BR levels result in dephosphorylation of BZR1, which facilitates the binding of dephosphorylated BZR1 (dBZR1) to conserved E-boxes (CANNTG) and/or BRRE elements (CGTGT/CG) in target BR-responsive genes' promoters (Figure 3) [131,132].

BRI1 activates BZR1 and BES1 downstream TFs for inducing stress tolerance $[19,47,133]$. Upon BR perception, BR signals are relayed to BES1 and BZR1 via a signaling cascade, which eventually controls the transcription of genes regulated by the BRs $[7,9,134,135]$. BAK1, another LRR receptor kinase, interacts with BRI1 and acts as a co-receptor. The bioactive form of BR, brassinolide (BL), enhances the interaction of BRI1 and BAK1 [136]. BAK1 triggers the intracellular signaling pathways that include the protein phosphatase BSU1, the serine/threonine-protein kinase BSK1, protein phosphatase 2A (PP2A) phosphatases, the Glycogen synthase kinase 3 (GSK3)-like kinase Brassinosteroid-insensitive 2 (BIN2), and BZR1 family TFs $[8,137]$. Therefore, mutations in genes encoding the BR synthesis and signaling pathways' main components cause limited plant yield and fertility, impaired growth and development of the organ, and severe dwarfism $[7,35]$. 


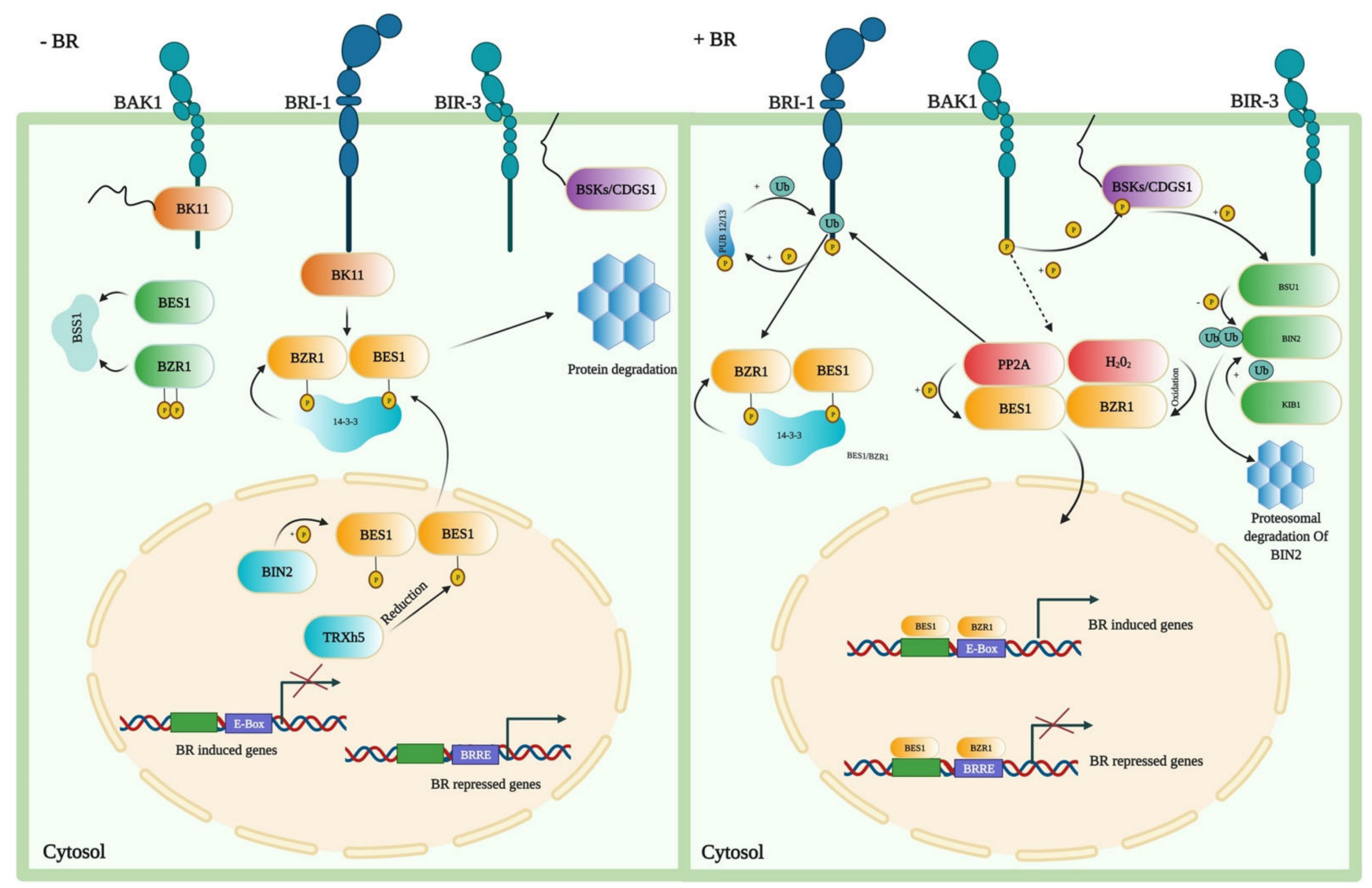

Figure 3. Signaling in the absence and presence of BRs in A. thaliana. When BRs are absent, BZR1 and BES1 proteins are being phosphorylated by the BIN2 that activates them by promoting binding of these proteins to the 14-3-3 proteins, resulting in cytoplasmic retention and degradation. This enhances the cytoplasmic retention of TFs, preventing them from entering the nucleus and terminating the response induced by the BR. When BRs are present, BR binding to BRI1 and the co-receptor BAK1 causes BKI1 to dissociate from BRI1 and causes trans-phosphorylation between BRI1 and BAK1. Through direct phosphorylation, the activated BRI1-BAK1 receptor complex transmits its signal to BSKs and Constitutive differential growth 1 (CDG1). BSU1 phosphatase is activated by BSKs or CDG1. BSU1 subsequently dephosphorylates the BIN2 to inactive it, and the E3 ligase KIB1 mediates the degradation of BIN2. Meanwhile, PP2A dephosphorylates BZR1 and BES1 to activate them, allowing TFs to enter the nucleus and regulate the expression of the BR target genes, either by direct interaction or through interactions with other TFs. Moreover, PP2A positively regulates BR signaling by the dephosphorylation of BZR1 and BES1, while the SBI1 (Suppressor of BRI1) deactivates the BRI1 through PP2A methylation.

Plant hormones often regulate the expression of a downstream gene through TFs. $B R$ regulates the development of plants via TFs that either repress or induce downstream genes [138]. BRs have received much research attention in the last two decades due to their crucial roles in plant development and crop yield enhancement. Consequently, the BR signaling cascade in plants is one of the well-studied signaling pathways [139]. Many TFs have been identified as being involved in downstream BR signaling pathways. In the BR signaling pathway, BES1 and BZR1 are considered to be essential TFs. BES1 has been found to be $88 \%$ identical with BZR1. It has similar protein domains: a nuclear localization signal (NLS) in the $\mathrm{N}$ terminal, a PEST domain in the $\mathrm{C}$ terminus, and a serine-rich domain in the center [49]. BES1/BZR1 also interacts with several TFs, including HAT1, MYB30, BIM1, and $M Y B L 2$, to induce or reduce the expression of downstream genes and incorporate the BR and other signaling pathways [138,140-143]. 


\section{Concluding Remarks and Future Perspectives}

Plants are mainly exposed to a number of biotic and abiotic stresses that negatively affect the plants and lead to the crop production loss. In a result, plants have adapted different mechanisms against these stresses, including the production of several phytohormones. BRs are the hormones that regulate numerous physiological and developmental processes. BRs play a crucial role in major plant antioxidant processes, including the regulation and increase in plant tolerance to various stresses. Over the last few decades, multiple studies on BRs have attracted the attention of plant scientists because of their involvement in various developmental and physiological processes in plants. In addition to their well-known functions in growth, they are now being discovered to play crucial roles in resistance to several biotic and abiotic stresses. BRs mediate these responses by regulating a wide range of genes. However, further research needs to be conducted to deeply understand the role of BRs in plant growth and development, and against various stresses in plants.

Author Contributions: The authors confirm their contributions to this work: H.M. in conceptualization, original draft preparation, and writing; and A.H., Q.A. and F.L. in revising, and review. All authors have read and agreed to the published version of the manuscript.

Funding: This work was supported by grant from the Lushan Botanical Garden, Chinese Academy of Sciences (No. 2021ZWZX28 to Hakim Manghwar), and by grant from the National Natural Science Foundation of China (32100297 to Fen Liu).

Institutional Review Board Statement: Not applicable.

Informed Consent Statement: Not applicable.

Data Availability Statement: Not applicable.

Acknowledgments: We apologize to the authors whose works are not cited because of space limitations.

Conflicts of Interest: The authors declare no conflict of interest.

\section{References}

1. Zhang, S.; Cai, Z.; Wang, X. The primary signaling outputs of brassinosteroids are regulated by abscisic acid signaling. Proc. Natl. Acad. Sci. USA 2009, 106, 4543-4548. [CrossRef] [PubMed]

2. Vardhini, B.V.; Anjum, N.A. Brassinosteroids make plant life easier under abiotic stresses mainly by modulating major components of antioxidant defense system. Front. Environ. Sci. 2015, 2, 67. [CrossRef]

3. Zhao, M.; Yuan, L.; Wang, J.; Xie, S.; Zheng, Y.; Nie, L.; Zhu, S.; Hou, J.; Chen, G.; Wang, C. Transcriptome analysis reveals a positive effect of brassinosteroids on the photosynthetic capacity of wucai under low temperature. BMC Genom. 2019, 20, 810. [CrossRef] [PubMed]

4. Wang, F.; Ahammed, G.J.; Li, G.; Bai, P.; Jiang, Y.; Wang, S.; Chen, S. Ethylene is involved in red light-induced anthocyanin biosynthesis in cabbage (Brassica oleracea). Int. J. Agric. Biol. 2019, 21, 955-963.

5. Verma, V.; Ravindran, P.; Kumar, P.P. Plant hormone-mediated regulation of stress responses. BMC Plant Biol. 2016, 16, 86. [CrossRef]

6. Xiong, L.; Schumaker, K.S.; Zhu, J.-K. Cell signaling during cold, drought, and salt stress. Plant Cell 2002, 14, S165-S183. [CrossRef]

7. Planas-Riverola, A.; Gupta, A.; Betegón-Putze, I.; Bosch, N.; Ibañes, M.; Caño-Delgado, A.I. Brassinosteroid signaling in plant development and adaptation to stress. Development 2019, 146, dev151894. [CrossRef]

8. Wang, Z.-Y.; Bai, M.-Y.; Oh, E.; Zhu, J.-Y. Brassinosteroid signaling network and regulation of photomorphogenesis. Annu. Rev. Genet. 2012, 46, 701-724. [CrossRef]

9. Tong, H.; Chu, C. Functional specificities of brassinosteroid and potential utilization for crop improvement. Trends Plant Sci. 2018, 23, 1016-1028. [CrossRef]

10. Mitchell, J.; Mandava, N.; Worley, J.; Plimmer, J.; Smith, M. Brassins-A new family of plant hormones from rape pollen. Nature 1970, 225, 1065-1066. [CrossRef]

11. Grove, M.D.; Spencer, G.F.; Rohwedder, W.K.; Mandava, N.; Worley, J.F.; Warthen, J.D.; Steffens, G.L.; Flippen-Anderson, J.L.; Cook, J.C. Brassinolide, a plant growth-promoting steroid isolated from Brassica napus pollen. Nature 1979, 281, $216-217$. [CrossRef]

12. Li, J.; Chory, J. A putative leucine-rich repeat receptor kinase involved in brassinosteroid signal transduction. Cell 1997, 90, 929-938. [CrossRef]

13. Kim, E.-J.; Russinova, E. Brassinosteroid signalling. Curr. Biol. 2020, 30, R294-R298. [CrossRef] [PubMed] 
14. Bajguz, A.; Tretyn, A. The chemical characteristic and distribution of brassinosteroids in plants. Phytochemistry 2003, 62, 1027-1046. [CrossRef]

15. Bajguz, A.; Tretyn, A. The chemical structures and occurrence of brassinosteroids in plants. In Brassinosteroids; Springer: Berlin/Heidelberg, Germany, 2003; pp. 1-44.

16. Hussain, M.A.; Fahad, S.; Sharif, R.; Jan, M.F.; Mujtaba, M.; Ali, Q.; Ahmad, A.; Ahmad, H.; Amin, N.; Ajayo, B.S. Multifunctional role of brassinosteroid and its analogues in plants. Plant Growth Regul. 2020, 92, 141-156. [CrossRef]

17. Bajguz, A. Brassinosteroids-occurence and chemical structures in plants. In Brassinosteroids: A Class of Plant Hormone; Springer: Berlin/Heidelberg, Germany, 2011; pp. 1-27.

18. Ohnishi, T. Recent advances in brassinosteroid biosynthetic pathway: Insight into novel brassinosteroid shortcut pathway. J. Pestic. Sci. 2018, 43, 159-167. [CrossRef] [PubMed]

19. Li, Z.; He, Y. Roles of Brassinosteroids in Plant Reproduction. Int. J. Mol. Sci. 2020, 21, 872. [CrossRef]

20. Hayat, S.; Ahmad, A.; Ahmad, A. Brassinosteroids: Bioactivity and Crop Productivity; Springer Science \& Business Media: Berlin/Heidelberg, Germany, 2003.

21. Fedina, E.; Yarin, A.; Mukhitova, F.; Blufard, A.; Chechetkin, I. Brassinosteroid-induced changes of lipid composition in leaves of Pisum sativum L. during senescence. Steroids 2017, 117, 25-28. [CrossRef]

22. Yokota, T.; Ohnishi, T.; Shibata, K.; Asahina, M.; Nomura, T.; Fujita, T.; Ishizaki, K.; Kohchi, T. Occurrence of brassinosteroids in non-flowering land plants, liverwort, moss, lycophyte and fern. Phytochemistry 2017, 136, 46-55. [CrossRef] [PubMed]

23. Fujioka, S.; Yokota, T. Biosynthesis and metabolism of brassinosteroids. Annu. Rev. Plant Biol. 2003, 54, 137-164. [CrossRef] [PubMed]

24. Zhu, Z.; Liang, H.; Chen, G.; Tang, B.; Tian, S.; Hu, Z. Isolation of the brassinosteroid receptor genes and recharacterization of dwarf plants by silencing of SIBRI1 in tomato. Plant Growth Regul. 2019, 89, 59-71. [CrossRef]

25. Zou, L.; Qu, M.; Zeng, L.; Xiong, G. The molecular basis of the interaction between Brassinosteroid induced and phosphorous deficiency induced leaf inclination in rice. Plant Growth Regul. 2020, 91, 263-276. [CrossRef]

26. Wendeborn, S.; Lachia, M.; Jung, P.M.; Leipner, J.; Brocklehurst, D.; De Mesmaeker, A.; Gaus, K.; Mondière, R. Biological Activity of Brassinosteroids-Direct Comparison of Known and New Analogs in planta. Helv. Chim. Acta 2017, 100, 1-46. [CrossRef]

27. Hayat, S.; Yusuf, M.; Bhardwaj, R.; Bajguz, A. Brassinosteroids: Plant Growth and Development; Springer: Berlin/Heidelberg, Germany, 2019.

28. Bajguz, A.; Chmur, M.; Gruszka, D. Comprehensive overview of the Brassinosteroid biosynthesis pathways: Substrates, products, inhibitors, and connections. Front. Plant Sci. 2020, 11, 1034. [CrossRef] [PubMed]

29. Kim, S.-K. Natural Occurrences of Brassinosteroids; ACS Symposium Series; American Chemical Society: Washington, DC, USA, 1991; pp. 26-35.

30. Bishop, G.J.; Nomura, T.; Yokota, T.; Harrison, K.; Noguchi, T.; Fujioka, S.; Takatsuto, S.; Jones, J.D.; Kamiya, Y. The tomato DWARF enzyme catalyses C-6 oxidation in brassinosteroid biosynthesis. Proc. Natl. Acad. Sci. USA 1999, 96, 1761-1766. [CrossRef]

31. Fujioka, S. Natural occurrence of brassinosteroids in the plant kingdom. In Brassinosteroid: Steroidal Plant Hormones; Springer: Amsterdam, The Netherlands, 1999; pp. 21-45.

32. Fang, P.; Yan, M.; Chi, C.; Wang, M.; Zhou, Y.; Zhou, J.; Shi, K.; Xia, X.; Foyer, C.H.; Yu, J. Brassinosteroids act as a positive regulator of photoprotection in response to chilling stress. Plant Physiol. 2019, 180, 2061-2076. [CrossRef]

33. Peres, A.L.G.; Soares, J.S.; Tavares, R.G.; Righetto, G.; Zullo, M.A.; Mandava, N.B.; Menossi, M. Brassinosteroids, the sixth class of phytohormones: A molecular view from the discovery to hormonal interactions in plant development and stress adaptation. Int. J. Mol. Sci. 2019, 20, 331. [CrossRef]

34. Lin, W.-H. Designed Manipulation of the Brassinosteroid Signal to Enhance Crop Yield. Front. Plant Sci. 2020, 11, 854. [CrossRef]

35. Singh, A.P.; Savaldi-Goldstein, S. Growth control: Brassinosteroid activity gets context. J. Exp. Bot. 2015, 66, 1123-1132. [CrossRef]

36. Fàbregas, N.; Caño-Delgado, A.I. Turning on the microscope turret: A new view for the study of brassinosteroid signaling in plant development. Physiol. Plant. 2014, 151, 172-183. [CrossRef]

37. Lv, B.; Tian, H.; Zhang, F.; Liu, J.; Lu, S.; Bai, M.; Li, C.; Ding, Z. Brassinosteroids regulate root growth by controlling reactive oxygen species homeostasis and dual effect on ethylene synthesis in Arabidopsis. PLoS Genet. 2018, 14, e1007144. [CrossRef] [PubMed]

38. Wang, Q.; Yu, F.; Xie, Q. Balancing growth and adaptation to stress: Crosstalk between brassinosteroid and abscisic acid signaling Plant Cell Environ. 2020, 43, 2325-2335. [CrossRef]

39. Oh, E.; Zhu, J.-Y.; Bai, M.-Y.; Arenhart, R.A.; Sun, Y.; Wang, Z.-Y. Cell elongation is regulated through a central circuit of interacting transcription factors in the Arabidopsis hypocotyl. eLife 2014, 3, e03031. [CrossRef] [PubMed]

40. Hacham, Y.; Holland, N.; Butterfield, C.; Ubeda-Tomas, S.; Bennett, M.J.; Chory, J.; Savaldi-Goldstein, S. Brassinosteroid perception in the epidermis controls root meristem size. Development 2011, 138, 839-848. [CrossRef]

41. Kim, T.-W.; Michniewicz, M.; Bergmann, D.C.; Wang, Z.-Y. Brassinosteroid regulates stomatal development by GSK3-mediated inhibition of a MAPK pathway. Nature 2012, 482, 419-422. [CrossRef]

42. Khan, M.; Rozhon, W.; Bigeard, J.; Pflieger, D.; Husar, S.; Pitzschke, A.; Teige, M.; Jonak, C.; Hirt, H.; Poppenberger, B Brassinosteroid-regulated GSK3/Shaggy-like kinases phosphorylate mitogen-activated protein (MAP) kinase kinases, which control stomata development in Arabidopsis thaliana. J. Biol. Chem. 2013, 288, 7519-7527. [CrossRef] 
43. Vogler, F.; Schmalzl, C.; Englhart, M.; Bircheneder, M.; Sprunck, S. Brassinosteroids promote Arabidopsis pollen germination and growth. Plant Reprod. 2014, 27, 153-167. [CrossRef] [PubMed]

44. Yamamoto, R.; Fujioka, S.; Demura, T.; Takatsuto, S.; Yoshida, S.; Fukuda, H. Brassinosteroid levels increase drastically prior to morphogenesis of tracheary elements. Plant Physiol. 2001, 125, 556-563. [CrossRef] [PubMed]

45. Saito, M.; Kondo, Y.; Fukuda, H. BES1 and BZR1 redundantly promote phloem and xylem differentiation. Plant Cell Physiol. 2018, 59, 590-600. [CrossRef] [PubMed]

46. Lee, J.; Han, S.; Lee, H.-Y.; Jeong, B.; Heo, T.-Y.; Hyun, T.K.; Kim, K.; Je, B.I.; Lee, H.; Shim, D. Brassinosteroids facilitate xylem differentiation and wood formation in tomato. Planta 2019, 249, 1391-1403. [CrossRef]

47. Nolan, T.M.; Vukašinović, N.; Liu, D.; Russinova, E.; Yin, Y. Brassinosteroids: Multidimensional regulators of plant growth, development, and stress responses. Plant Cell 2020, 32, 295-318. [CrossRef]

48. Ahammed, G.J.; Li, X.; Liu, A.; Chen, S. Brassinosteroids in Plant Tolerance to Abiotic Stress. J. Plant Growth Regul. 2020, 39 , 1451-1464. [CrossRef]

49. Yin, Y.; Wang, Z.-Y.; Mora-Garcia, S.; Li, J.; Yoshida, S.; Asami, T.; Chory, J. BES1 accumulates in the nucleus in response to brassinosteroids to regulate gene expression and promote stem elongation. Cell 2002, 109, 181-191. [CrossRef]

50. Zadvornova, Y.; Alekseichuk, G.; Laman, N.; Khripach, V.; Grut, S. Effect of brassinosteroids on activation of the cell cycle during germination of Brassica oleracea L. seeds. Doklady Natsional'noi Akademii Nauk Belarusi 2005, 49, 70-73.

51. González-García, M.-P.; Vilarrasa-Blasi, J.; Zhiponova, M.; Divol, F.; Mora-García, S.; Russinova, E.; Caño-Delgado, A.I. Brassinosteroids control meristem size by promoting cell cycle progression in Arabidopsis roots. Development 2011, 138, 849-859. [CrossRef]

52. Nakaya, M.; Tsukaya, H.; Murakami, N.; Kato, M. Brassinosteroids control the proliferation of leaf cells of Arabidopsis thaliana Plant Cell Physiol. 2002, 43, 239-244. [CrossRef] [PubMed]

53. Arteca, J.M.; Arteca, R.N. Brassinosteroid-induced exaggerated growth in hydroponically grown Arabidopsis plants. Physiol. Plant. 2001, 112, 104-112. [CrossRef]

54. Ackerman-Lavert, M.; Savaldi-Goldstein, S. Growth models from a brassinosteroid perspective. Curr. Opin. Plant Biol. 2020, 53, 90-97. [CrossRef]

55. Makarevitch, I.; Thompson, A.; Muehlbauer, G.J.; Springer, N.M. Brd1 gene in maize encodes a brassinosteroid C-6 oxidase. PLoS ONE 2012, 7, e30798.

56. Hartwig, T.; Chuck, G.S.; Fujioka, S.; Klempien, A.; Weizbauer, R.; Potluri, D.P.V.; Choe, S.; Johal, G.S.; Schulz, B. Brassinosteroid control of sex determination in maize. Proc. Natl. Acad. Sci. USA 2011, 108, 19814-19819. [CrossRef]

57. Jaillais, Y.; Vert, G. Brassinosteroids, gibberellins and light-mediated signalling are the three-way controls of plant sprouting. Nat. Cell Biol. 2012, 14, 788-790. [CrossRef]

58. Zhu, X.; Liang, W.; Cui, X.; Chen, M.; Yin, C.; Luo, Z.; Zhu, J.; Lucas, W.J.; Wang, Z.; Zhang, D. Brassinosteroids promote development of rice pollen grains and seeds by triggering expression of Carbon Starved Anther, a MYB domain protein. Plant J. 2015, 82, 570-581. [CrossRef] [PubMed]

59. Jaiswal, S.; Båga, M.; Chibbar, R.N. Brassinosteroid receptor mutation influences starch granule size distribution in barley grains Plant Physiol. Biochem. 2020, 154, 369-378. [CrossRef]

60. Divi, U.K.; Krishna, P. Brassinosteroid: A biotechnological target for enhancing crop yield and stress tolerance. New Biotechnol. 2009, 26, 131-136. [CrossRef] [PubMed]

61. Chen, J.; Nolan, T.M.; Ye, H.; Zhang, M.; Tong, H.; Xin, P.; Chu, J.; Chu, C.; Li, Z.; Yin, Y. Arabidopsis WRKY46, WRKY54, and WRKY70 transcription factors are involved in brassinosteroid-regulated plant growth and drought responses. Plant Cell 2017, 29, 1425-1439. [CrossRef] [PubMed]

62. Wang, X.; Chen, J.; Xie, Z.; Liu, S.; Nolan, T.; Ye, H.; Zhang, M.; Guo, H.; Schnable, P.S.; Li, Z. Histone lysine methyltransferase SDG8 is involved in brassinosteroid-regulated gene expression in Arabidopsis thaliana. Mol. Plant 2014, 7, 1303-1315. [CrossRef]

63. Huang, H.-Y.; Jiang, W.-B.; Hu, Y.-W.; Wu, P.; Zhu, J.-Y.; Liang, W.-Q.; Wang, Z.-Y.; Lin, W.-H. BR signal influences Arabidopsis ovule and seed number through regulating related genes expression by BZR1. Mol. Plant 2013, 6, 456-469. [CrossRef] [PubMed]

64. Jiang, W.-B.; Huang, H.-Y.; Hu, Y.-W.; Zhu, S.-W.; Wang, Z.-Y.; Lin, W.-H. Brassinosteroid regulates seed size and shape in Arabidopsis. Plant Physiol. 2013, 162, 1965-1977. [CrossRef]

65. Jia, Z.; Giehl, R.F.; Meyer, R.C.; Altmann, T.; von Wirén, N. Natural variation of BSK3 tunes brassinosteroid signaling to regulate root foraging under low nitrogen. Nat. Commun. 2019, 10, 2378. [CrossRef]

66. Tanabe, S.; Ashikari, M.; Fujioka, S.; Takatsuto, S.; Yoshida, S.; Yano, M.; Yoshimura, A.; Kitano, H.; Matsuoka, M.; Fujisawa, Y. A novel cytochrome $\mathrm{P} 450$ is implicated in brassinosteroid biosynthesis via the characterization of a rice dwarf mutant, dwarf11, with reduced seed length. Plant Cell 2005, 17, 776-790. [CrossRef]

67. Hong, Z.; Ueguchi-Tanaka, M.; Fujioka, S.; Takatsuto, S.; Yoshida, S.; Hasegawa, Y.; Ashikari, M.; Kitano, H.; Matsuoka, M. The rice brassinosteroid-deficient dwarf2 mutant, defective in the rice homolog of Arabidopsis DIMINUTO/DWARF1, is rescued by the endogenously accumulated alternative bioactive brassinosteroid, dolichosterone. Plant Cell 2005, 17, 2243-2254. [CrossRef]

68. Zhang, W.; Zhu, K.; Wang, Z.; Zhang, H.; Gu, J.; Liu, L.; Yang, J.; Zhang, J. Brassinosteroids function in spikelet differentiation and degeneration in rice. J. Integr. Plant Biol. 2019, 61, 943-963. [CrossRef]

69. Sun, Y.; Veerabomma, S.; Abdel-Mageed, H.A.; Fokar, M.; Asami, T.; Yoshida, S.; Allen, R.D. Brassinosteroid regulates fiber development on cultured cotton ovules. Plant Cell Physiol. 2005, 46, 1384-1391. [CrossRef] 
70. Luo, M.; Xiao, Y.; Li, X.; Lu, X.; Deng, W.; Li, D.; Hou, L.; Hu, M.; Li, Y.; Pei, Y. GhDET2, a steroid $5 \alpha$-reductase, plays an important role in cotton fiber cell initiation and elongation. Plant J. 2007, 51, 419-430. [CrossRef]

71. Janeczko, A.; Oklestkova, J.; Novak, O.; Śniegowska-Świerk, K.; Snaczke, Z.; Pociecha, E. Disturbances in production of progesterone and their implications in plant studies. Steroids 2015, 96, 153-163. [CrossRef]

72. Wan, L.; Zhang, F.; Zhang, L.; Liu, L.; Chen, C.; Ma, N.; Zhang, C. Brassinosteroids promote seed development and physiological maturity of oilseed rape (Brassica napus L.). Oil Crop Sci. 2017, 1, 122-130.

73. Zhang, S.; Hu, J.; Zhang, Y.; Xie, X.; Knapp, A. Seed priming with brassinolide improves lucerne (Medicago sativa L.) seed germination and seedling growth in relation to physiological changes under salinity stress. Aust. J. Agric. Res. 2007, 58, 811-815. [CrossRef]

74. Symons, G.M.; Davies, C.; Shavrukov, Y.; Dry, I.B.; Reid, J.B.; Thomas, M.R. Grapes on steroids. Brassinosteroids are involved in grape berry ripening. Plant Physiol. 2006, 140, 150-158. [CrossRef]

75. Xu, F.; Xi, Z.-m.; Zhang, H.; Zhang, C.-j.; Zhang, Z.-w. Brassinosteroids are involved in controlling sugar unloading in Vitis vinifera 'Cabernet Sauvignon' berries during véraison. Plant Physiol. Biochem. 2015, 94, 197-208. [CrossRef] [PubMed]

76. Zhu, Z.; Zhang, Z.; Qin, G.; Tian, S. Effects of brassinosteroids on postharvest disease and senescence of jujube fruit in storage. Postharvest Biol. Technol. 2010, 56, 50-55. [CrossRef]

77. Meudt, W.; Thompson, M.; Bennett, H. Investigations on the Mechanism of the Brassinosteroid Response. III. Techniques for Potential Enhancement of Crop Production [Barley, Bean]. In Proceedings Annual Meeting; Plant Growth Regulator Society of America: Madison, WI, USA, 1983; pp. 312-318.

78. Oh, M.-H. Brassinosteroids accelerate the rate of cell division in isolated petal protoplasts of Petunia hybrida. J. Plant Biotechnol. 2003, 5, 69-77.

79. Kęsy, J.; Trzaskalska, A.; Galoch, E.; Kopcewicz, J. Inhibitory effect of brassinosteroids on the flowering of the short-day plant Pharbitis nil. Biol. Plant. 2003, 47, 597-600. [CrossRef]

80. Trevisan, S.; Forestan, C.; Brojanigo, S.; Quaggiotti, S.; Varotto, S. Brassinosteroid application affects the growth and gravitropic response of maize by regulating gene expression in the roots, shoots and leaves. Plant Growth Regul. 2020, 92, 117-130. [CrossRef]

81. Ahammed, G.J.; Li, X.; Xia, X.-J.; Shi, K.; Zhou, Y.-H.; Yu, J.-Q. Enhanced photosynthetic capacity and antioxidant potential mediate brassinosteriod-induced phenanthrene stress tolerance in tomato. Environ. Pollut. 2015, 201, 58-66. [CrossRef]

82. Ye, Q.; Zhu, W.; Li, L.; Zhang, S.; Yin, Y.; Ma, H.; Wang, X. Brassinosteroids control male fertility by regulating the expression of key genes involved in Arabidopsis anther and pollen development. Proc. Natl. Acad. Sci. USA 2010, 107, 6100-6105. [CrossRef]

83. Domagalska, M.A.; Sarnowska, E.; Nagy, F.; Davis, S.J. Genetic analyses of interactions among gibberellin, abscisic acid, and brassinosteroids in the control of flowering time in Arabidopsis thaliana. PLoS ONE 2010, 5, e14012. [CrossRef]

84. Li, J.; Nagpal, P.; Vitart, V.; McMorris, T.C.; Chory, J. A role for brassinosteroids in light-dependent development of Arabidopsis. Science 1996, 272, 398-401. [CrossRef] [PubMed]

85. Gudesblat, G.E.; Schneider-Pizoń, J.; Betti, C.; Mayerhofer, J.; Vanhoutte, I.; Van Dongen, W.; Boeren, S.; Zhiponova, M.; De Vries, S.; Jonak, C. SPEECHLESS integrates brassinosteroid and stomata signalling pathways. Nat. Cell Biol. 2012, 14, 548-554. [CrossRef] [PubMed]

86. Zhu, J.-Y.; Sae-Seaw, J.; Wang, Z.-Y. Brassinosteroid signalling. Development 2013, 140, 1615-1620. [CrossRef]

87. Clouse, S.D. The molecular intersection of brassinosteroid-regulated growth and flowering in Arabidopsis. Proc. Natl. Acad. Sci. USA 2008, 105, 7345-7346. [CrossRef] [PubMed]

88. Zhao, B.; Li, J. Regulation of brassinosteroid biosynthesis and inactivation F. J. Integr. Plant Biol. 2012, 54, 746-759. [CrossRef]

89. Rozhon, W.; Akter, S.; Fernandez, A.; Poppenberger, B. Inhibitors of brassinosteroid biosynthesis and signal transduction. Molecules 2019, 24, 4372. [CrossRef]

90. Xie, L.; Yang, C.; Wang, X. Brassinosteroids can regulate cellulose biosynthesis by controlling the expression of CESA genes in Arabidopsis. J. Exp. Bot. 2011, 62, 4495-4506. [CrossRef]

91. Li, Z.; Ou, Y.; Zhang, Z.; Li, J.; He, Y. Brassinosteroid signaling recruits histone 3 lysine-27 demethylation activity to FLOWERING LOCUS C chromatin to inhibit the floral transition in Arabidopsis. Mol. Plant 2018, 11, 1135-1146. [CrossRef]

92. Wang, Y.; Cao, J.-J.; Wang, K.-X.; Xia, X.-J.; Shi, K.; Zhou, Y.-H.; Yu, J.-Q.; Zhou, J. BZR1 mediates brassinosteroid-induced autophagy and nitrogen starvation in tomato. Plant Physiol. 2019, 179, 671-685. [CrossRef]

93. Zheng, T.; Dong, T.; Haider, M.S.; Jin, H.; Jia, H.; Fang, J. Brassinosteroid Regulates 3-Hydroxy-3-methylglutaryl CoA Reductase to Promote Grape Fruit Development. J. Agric. Food Chem. 2020, 68, 11987-11996. [CrossRef]

94. Anjum, S.; Wang, L.; Farooq, M.; Hussain, M.; Xue, L.; Zou, C. Brassinolide application improves the drought tolerance in maize through modulation of enzymatic antioxidants and leaf gas exchange. J. Agron. Crop Sci. 2011, 197, 177-185. [CrossRef]

95. Divi, U.K.; Rahman, T.; Krishna, P. Gene expression and functional analyses in brassinosteroid-mediated stress tolerance. Plant Biotechnol. J. 2016, 14, 419-432. [CrossRef] [PubMed]

96. Fàbregas, N.; Lozano-Elena, F.; Blasco-Escámez, D.; Tohge, T.; Martínez-Andújar, C.; Albacete, A.; Osorio, S.; Bustamante, M.; Riechmann, J.L.; Nomura, T. Overexpression of the vascular brassinosteroid receptor BRL3 confers drought resistance without penalizing plant growth. Nat. Commun. 2018, 9, 4680. [CrossRef] [PubMed]

97. Lima, J.; Lobato, A. Brassinosteroids improve photosystem II efficiency, gas exchange, antioxidant enzymes and growth of cowpea plants exposed to water deficit. Physiol. Mol. Biol. Plants 2017, 23, 59-72. [CrossRef] [PubMed] 
98. Eremina, M.; Unterholzner, S.J.; Rathnayake, A.I.; Castellanos, M.; Khan, M.; Kugler, K.G.; May, S.T.; Mayer, K.F.; Rozhon, W.; Poppenberger, B. Brassinosteroids participate in the control of basal and acquired freezing tolerance of plants. Proc. Natl. Acad. Sci. USA 2016, 113, E5982-E5991. [CrossRef] [PubMed]

99. Li, H.; Ye, K.; Shi, Y.; Cheng, J.; Zhang, X.; Yang, S. BZR1 positively regulates freezing tolerance via CBF-dependent and CBF-independent pathways in Arabidopsis. Mol. Plant 2017, 10, 545-559. [CrossRef]

100. Yin, Y.; Qin, K.; Song, X.; Zhang, Q.; Zhou, Y.; Xia, X.; Yu, J. BZR1 transcription factor regulates heat stress tolerance through FERONIA receptor-like kinase-mediated reactive oxygen species signaling in tomato. Plant Cell Physiol. 2018, 59, $2239-2254$. [CrossRef]

101. Ibañez, C.; Delker, C.; Martinez, C.; Bürstenbinder, K.; Janitza, P.; Lippmann, R.; Ludwig, W.; Sun, H.; James, G.V.; Klecker, M. Brassinosteroids dominate hormonal regulation of plant thermomorphogenesis via BZR1. Curr. Biol. 2018, 28, 303-310.e3. [CrossRef]

102. Cui, F.; Liu, L.; Zhao, Q.; Zhang, Z.; Li, Q.; Lin, B.; Wu, Y.; Tang, S.; Xie, Q. Arabidopsis ubiquitin conjugase UBC32 is an ERAD component that functions in brassinosteroid-mediated salt stress tolerance. Plant Cell 2012, 24, 233-244. [CrossRef] [PubMed]

103. Zhu, T.; Deng, X.; Zhou, X.; Zhu, L.; Zou, L.; Li, P.; Zhang, D.; Lin, H. Ethylene and hydrogen peroxide are involved in brassinosteroid-induced salt tolerance in tomato. Sci. Rep. 2016, 6, 35392. [CrossRef]

104. Rajewska, I.; Talarek, M.; Bajguz, A. Brassinosteroids and response of plants to heavy metals action. Front. Plant Sci. 2016, 7, 629. [CrossRef] [PubMed]

105. Shahzad, B.; Tanveer, M.; Che, Z.; Rehman, A.; Cheema, S.A.; Sharma, A.; Song, H.; ur Rehman, S.; Zhaorong, D. Role of 24-epibrassinolide (EBL) in mediating heavy metal and pesticide induced oxidative stress in plants: A review. Ecotoxicol. Environ. Saf. 2018, 147, 935-944. [CrossRef] [PubMed]

106. Hao, J.; Yin, Y.; Fei, S.-z. Brassinosteroid signaling network: Implications on yield and stress tolerance. Plant Cell Rep. 2013, 32, 1017-1030. [CrossRef]

107. Wu, C.; Li, F.; Xu, H.; Zeng, W.; Yu, R.; Wu, X.; Shen, L.; Liu, Y.; Li, J. The potential role of brassinosteroids (BRs) in alleviating antimony (Sb) stress in Arabidopsis thaliana. Plant Physiol. Biochem. 2019, 141, 51-59. [CrossRef]

108. Fridman, Y.; Savaldi-Goldstein, S. Brassinosteroids in growth control: How, when and where. Plant Sci. 2013, 209, 24-31. [CrossRef] [PubMed]

109. Kagale, S.; Divi, U.K.; Krochko, J.E.; Keller, W.A.; Krishna, P. Brassinosteroid confers tolerance in Arabidopsis thaliana and Brassica napus to a range of abiotic stresses. Planta 2007, 225, 353-364. [CrossRef]

110. Sahni, S.; Prasad, B.D.; Liu, Q.; Grbic, V.; Sharpe, A.; Singh, S.P.; Krishna, P. Overexpression of the brassinosteroid biosynthetic gene DWF4 in Brassica napus simultaneously increases seed yield and stress tolerance. Sci. Rep. 2016, 6, 28298. [CrossRef] [PubMed]

111. Nakashita, H.; Yasuda, M.; Nitta, T.; Asami, T.; Fujioka, S.; Arai, Y.; Sekimata, K.; Takatsuto, S.; Yamaguchi, I.; Yoshida, S. Brassinosteroid functions in a broad range of disease resistance in tobacco and rice. Plant J. 2003, 33, 887-898. [CrossRef]

112. Zhang, D.-W.; Deng, X.-G.; Fu, F.-Q.; Lin, H.-H. Induction of plant virus defense response by brassinosteroids and brassinosteroid signaling in Arabidopsis thaliana. Planta 2015, 241, 875-885. [CrossRef]

113. Chi, C.; Li, X.; Fang, P.; Xia, X.; Shi, K.; Zhou, Y.; Zhou, J.; Yu, J. Brassinosteroids act as a positive regulator of NBR1-dependent selective autophagy in response to chilling stress in tomato. J. Exp. Bot. 2020, 71, 1092-1106. [CrossRef]

114. Soares, C.; de Sousa, A.; Pinto, A.; Azenha, M.; Teixeira, J.; Azevedo, R.A.; Fidalgo, F. Effect of 24-epibrassinolide on ROS content, antioxidant system, lipid peroxidation and Ni uptake in Solanum nigrum L. under Ni stress. Environ. Exp. Bot. 2016, 122, 115-125. [CrossRef]

115. Zhou, Y.-1.; Huo, S.-f.; Wang, L.-t.; Meng, J.-f.; Zhang, Z.-w.; Xi, Z.-m. Exogenous 24-Epibrassinolide alleviates oxidative damage from copper stress in grape (Vitis vinifera L.) cuttings. Plant Physiol. Biochem. 2018, 130, 555-565. [CrossRef] [PubMed]

116. Huang, Y.; Zhao, L.; Kong, Q.; Cheng, F.; Niu, M.; Xie, J.; Nawaz, M.A.; Bie, Z. Comprehensive mineral nutrition analysis of watermelon grafted onto two different rootstocks. Hortic. Plant J. 2016, 2, 105-113. [CrossRef]

117. Hasan, S.A.; Hayat, S.; Ahmad, A. Brassinosteroids protect photosynthetic machinery against the cadmium induced oxidative stress in two tomato cultivars. Chemosphere 2011, 84, 1446-1451. [CrossRef]

118. Zhou, J.; Wang, J.; Li, X.; Xia, X.-J.; Zhou, Y.-H.; Shi, K.; Chen, Z.; Yu, J.-Q. $\mathrm{H}_{2} \mathrm{O}_{2}$ mediates the crosstalk of brassinosteroid and abscisic acid in tomato responses to heat and oxidative stresses. J. Exp. Bot. 2014, 65, 4371-4383. [CrossRef]

119. Xia, X.-J.; Wang, Y.-J.; Zhou, Y.-H.; Tao, Y.; Mao, W.-H.; Shi, K.; Asami, T.; Chen, Z.; Yu, J.-Q. Reactive oxygen species are involved in brassinosteroid-induced stress tolerance in cucumber. Plant Physiol. 2009, 150, 801-814. [CrossRef] [PubMed]

120. Xiao, B.-Z.; Chen, X.; Xiang, C.-B.; Tang, N.; Zhang, Q.-F.; Xiong, L.-Z. Evaluation of seven function-known candidate genes for their effects on improving drought resistance of transgenic rice under field conditions. Mol. Plant 2009, 2, 73-83. [CrossRef]

121. Zeng, H.; Tang, Q.; Hua, X. Arabidopsis brassinosteroid mutants det2-1 and bin2-1 display altered salt tolerance. J. Plant Growth Regul. 2010, 29, 44-52. [CrossRef]

122. Li, B.; Zhang, C.; Cao, B.; Qin, G.; Wang, W.; Tian, S. Brassinolide enhances cold stress tolerance of fruit by regulating plasma membrane proteins and lipids. Amino Acids 2012, 43, 2469-2480. [CrossRef]

123. Ahammed, G.J.; Gao, C.-J.; Ogweno, J.O.; Zhou, Y.-H.; Xia, X.-J.; Mao, W.-H.; Shi, K.; Yu, J.-Q. Brassinosteroids induce plant tolerance against phenanthrene by enhancing degradation and detoxification in Solanum lycopersicum L. Ecotoxicol. Environ. Saf. 2012, 80, 28-36. [CrossRef] 
124. Schmitz, A.J.; Folsom, J.J.; Jikamaru, Y.; Ronald, P.; Walia, H. SUB 1 A-mediated submergence tolerance response in rice involves differential regulation of the brassinosteroid pathway. New Phytol. 2013, 198, 1060-1070. [CrossRef]

125. Deng, X.-G.; Zhu, T.; Zhang, D.-W.; Lin, H.-H. The alternative respiratory pathway is involved in brassinosteroid-induced environmental stress tolerance in Nicotiana benthamiana. J. Exp. Bot. 2015, 66, 6219-6232. [CrossRef] [PubMed]

126. Sharma, I. Studies on Brassinosteroid Mediated Responses in Oryza sativa L. under Pesticide and Salt Stress Employing Molecular and Biochemical Approaches. Ph.D. Thesis, Guru Nanak Dev University, Amritsar, India, 2014.

127. Sharma, I.; Bhardwaj, R.; Pati, P.K. Mitigation of adverse effects of chlorpyrifos by 24-epibrassinolide and analysis of stress markers in a rice variety Pusa Basmati-1. Ecotoxicol. Environ. Saf. 2012, 85, 72-81. [CrossRef] [PubMed]

128. Sharma, I.; Bhardwaj, R.; Pati, P.K. Exogenous application of 28-homobrassinolide modulates the dynamics of salt and pesticides induced stress responses in an elite rice variety Pusa Basmati-1. J. Plant Growth Regul. 2015, 34, 509-518. [CrossRef]

129. Wei, L.; Deng, X.-G.; Zhu, T.; Zheng, T.; Li, P.-X.; Wu, J.-Q.; Zhang, D.-W.; Lin, H.-H. Ethylene is involved in brassinosteroids induced alternative respiratory pathway in cucumber (Cucumis sativus L.) seedlings response to abiotic stress. Front. Plant Sci. 2015, 6, 982. [CrossRef] [PubMed]

130. Clouse, S.D. Brassinosteroid signal transduction: From receptor kinase activation to transcriptional networks regulating plant development. Plant Cell 2011, 23, 1219-1230. [CrossRef] [PubMed]

131. Kim, T.-W.; Wang, Z.-Y. Brassinosteroid signal transduction from receptor kinases to transcription factors. Annu. Rev. Plant Biol. 2010, 61, 681-704. [CrossRef] [PubMed]

132. Tang, W.; Yuan, M.; Wang, R.; Yang, Y.; Wang, C.; Oses-Prieto, J.A.; Kim, T.-W.; Zhou, H.-W.; Deng, Z.; Gampala, S.S. PP2A activates brassinosteroid-responsive gene expression and plant growth by dephosphorylating BZR1. Nat. Cell Biol. 2011, 13, 124-131. [CrossRef] [PubMed]

133. Northey, J.G.; Liang, S.; Jamshed, M.; Deb, S.; Foo, E.; Reid, J.B.; McCourt, P.; Samuel, M.A. Farnesylation mediates brassinosteroid biosynthesis to regulate abscisic acid responses. Nat. Plants 2016, 2, 16114. [CrossRef]

134. Praveena, J.; Dash, S.; Behera, L.; Rout, G.R. Brassinosteroids: A Multifunctional Phytohormone of Plant Development and Stress Responses. Curr. J. Appl. Sci. Technol. 2020, 39, 174-196. [CrossRef]

135. Aldukhi, F.; Deb, A.; Zhao, C.; Moffett, A.S.; Shukla, D. Molecular Mechanism of Brassinosteroid Perception by the Plant Growth Receptor BRI1. J. Phys. Chem. B 2019, 124, 355-365. [CrossRef]

136. Sun, Y.; Han, Z.; Tang, J.; Hu, Z.; Chai, C.; Zhou, B.; Chai, J. Structure reveals that BAK1 as a co-receptor recognizes the BRI1-bound brassinolide. Cell Res. 2013, 23, 1326-1329. [CrossRef]

137. Lee, H.G.; Won, J.H.; Choi, Y.-R.; Lee, K.; Seo, P.J. Brassinosteroids Regulate Circadian Oscillation via the BES1/TPL-CCA1/LHY Module in Arabidopsis thaliana. Iscience 2020, 23, 101528. [CrossRef]

138. Liu, X.; Yang, H.; Wang, Y.; Zhu, Z.; Zhang, W.; Li, J. Comparative transcriptomic analysis to identify brassinosteroid response genes. Plant Physiol. 2020, 184, 1072-1082. [CrossRef]

139. Vukašinović, N.; Russinova, E. BRexit: Possible brassinosteroid export and transport routes. Trends Plant Sci. 2018, 23, 285-292. [CrossRef] [PubMed]

140. Yin, Y.; Vafeados, D.; Tao, Y.; Yoshida, S.; Asami, T.; Chory, J. A new class of transcription factors mediates brassinosteroidregulated gene expression in Arabidopsis. Cell 2005, 120, 249-259. [CrossRef]

141. Li, L.; Yu, X.; Thompson, A.; Guo, M.; Yoshida, S.; Asami, T.; Chory, J.; Yin, Y. Arabidopsis MYB30 is a direct target of BES1 and cooperates with BES1 to regulate brassinosteroid-induced gene expression. Plant J. 2009, 58, 275-286. [CrossRef] [PubMed]

142. Ye, H.; Li, L.; Guo, H.; Yin, Y. MYBL2 is a substrate of GSK3-like kinase BIN2 and acts as a corepressor of BES1 in brassinosteroid signaling pathway in Arabidopsis. Proc. Natl. Acad. Sci. USA 2012, 109, 20142-20147. [CrossRef] [PubMed]

143. Zhang, D.; Ye, H.; Guo, H.; Johnson, A.; Zhang, M.; Lin, H.; Yin, Y. Transcription factor HAT 1 is phosphorylated by BIN 2 kinase and mediates brassinosteroid repressed gene expression in Arabidopsis. Plant J. 2014, 77, 59-70. [CrossRef] 